\title{
The Relationship between Children's Gender and the Divorce Rate
}

\author{
Chirag Malhotra, Siddharth Sarda and Guanru Wang
}

ABSTRACT

In this paper we analyse the impact of the gender of children on the stability of marriage. In order to analyse the issue we have conducted a survey with 40 people as well as utilised various economic theories such as the "father involvement hypothesis" (Morgan at al 1988), and Durkheim's division of labour theory (1893). We conclude that having a male child can reduce the odds of divorce. 


\section{INTRODUCTION}

This topic is intriguing primarily because the topic is as old as mankind itself. Previous studies have shown that the gender composition of a family's children - particularly, the presence of male child - reduces the chances of divorce. Using a survey and an economic interpretation, we analyse the channels in which this might operate. To explain the findings of our survey we use of the 'father-involvement' hypothesis by Morgan et al (1988). The hypothesis suggests that on average, the roles played by a father are greater with their male child and as a result they end up spending more time with their male child than with their female child. In turn the higher the level of a father's involvement in the marriage, the lower is the odds of divorce. However the same is not observed in women's involvement (White 1990). From an economic point of view the divorce rate is reciprocally associated with the specific investments made in a marriage by both the father and the mother. (Becker et al. 1977).

A father's presence and involvement during a child's raising may result in various types of division of labour amongst the family. Durkheim's (1893) theory says that fathers who have more presence during a child's rearing may result in the creation of an additional dependence amongst spouses. There will be an increased division of labour within the household, where husband and wife tend to be more reliant on the other to fulfil their economic function. This form of solidarity is called 'organic solidarity' by Durkheim because individuals with different functions and mentalities are contracting with each other. Taken together with Morgan et al's hypothesis, we can say that families with boys tend to exercise more organic solidarity (Diekmann \& Schmidheiny 2002).

\section{DEMAND FOR CHILDREN}

Marriage is a market. People transact in it primarily because it can produce a benefit that other markets cannot; for instance, the benefits of having a family, a new life, living with the people you love and the development of positive emotions. If people invest and fail to get the expected returns, they may want a divorce. Since children are an important product of the marriage market, we begin the analysis by analysing the difference in the demand for 
children across genders. An overall high demand for boys may increase the stability of a marriage that has many boys. Morgan et al's (1988) hypothesis would further suggest that fathers will have a stronger demand for boys.

In order to gauge demand for children according to gender, we conducted a survey of 40 people (10 married couples, 10 single males and 10 single females) with two questions. All of the subjects are aged between $21-35$, are Australian residents and are not living with their parents. The married couples are working fulltime and the rest are students. The questions and relevant results are the following:

\section{Question one}

What is the preferred gender for your child?*

\begin{tabular}{|c|c|}
\hline Male (male/ female ratio) & Female (male/ female ratio) \\
\hline $27(14 / 13)$ & $13(6 / 7)$ \\
\hline
\end{tabular}

*Figures in brackets indicate the ratio of respondents according to gender

For the first question, 27 people prefer to have a male child (includes 14 male and 13 female) and 13 people prefer a female child to a male child (includes 6 male and 7 female).

The survey shows two points:

1. Firstly, the overall demand for male children is higher than the demand for female child. From a simple preference viewpoint, couples will be more satisfied with their marriage if they had a male child. From a Beckerian investment viewpoint, divorces should also be less likely.

2. Secondly, there seems to be little difference between the gender preferences of males and females, which both genders nearly equally represented in preference for both male and female children. Contrary to the Morgan et al (1988) hypothesis, men do not prefer to have boys. 


\section{Question two}

If your first child's gender does not satisfy your expectations, would you choose to have a second child?*

\begin{tabular}{|c|c|c|}
\hline & $\begin{array}{c}\text { Yes (want male child/want } \\
\text { female child) }\end{array}$ & $\begin{array}{c}\text { No }(\text { want male child/want } \\
\text { female child) }\end{array}$ \\
\hline Male & $15(11 / 4=2.75)$ & $5(3 / 2=1.5)$ \\
\hline Female & $11(8 / 3=2.67)$ & $9(5 / 4=1.25)$ \\
\hline
\end{tabular}

*Figures in brackets indicate the ratio of respondents according to gender preferences

The table shows two points:

1. Firstly, men tend to a stronger preference for a child with their expected gender. As the data shows, the majority of men are willing to have a second child and the demand for boys are higher.

2. Secondly, people who want a male child are more willing to have a second child than people who want a female child. No matter male or female, the amounts for "want male child" are higher than the amounts of "want female child". This result shows that people who want a male child are more likely to have a second child if the first child is female, supporting the findings from the first question.

The overview of questions 1 and 2 tell us that the demand for a male child is higher than the demand for a female child. In other words, most people invest in the market of marriage with a hope of getting the benefit of male child. Furthermore, men are more persistent in obtaining a child of their preferred gender, and they are even more so if they prefer a male child. 


\section{THE RELATIONSHIP BETWEEN CHILDREN AND PARENTS}

Given that we have analysed demand, we now look at how children affect the relationship between a father and mother.

This part of the survey has eight questions and the results are as follows*:

\begin{tabular}{|c|c|c|}
\hline Question & Father & Mother \\
\hline 1. Who do you prefer to share your secrets with? & $10(6 / 4)$ & $30(14 / 16)$ \\
\hline 2. Who do you prefer to tell first when you make a mistake? & $11(5 / 6)$ & $29(15 / 14)$ \\
\hline $\begin{array}{c}\text { 3. Who do you protect/support more when your parents argue about } \\
\text { something? }\end{array}$ & $12(3 / 9)$ & $29(18 / 11)$ \\
\hline 4. Who do you prefer to play with? & $19(14 / 5)$ & $21(6 / 15)$ \\
\hline 5. Who do you prefer to work with? & $26(16 / 10)$ & $14(4 / 10)$ \\
\hline
\end{tabular}

* Figures in brackets indicate the ratio of respondents according to gender

The data suggests that mothers have a closer relationship with both male child and female child than the father since the mother scores higher in all questions except preference for working (question 5). However, the Morgan et al (1988) hypothesis finds some support in question 4 , where males tend to prefer to play with their fathers.

\begin{tabular}{|c|c|c|}
\hline Question & Father & Mother \\
\hline 6. Who has more income? & $31(18 / 13)$ & $9(2 / 7)$ \\
\hline 7. Who makes the final decision? & $25(14 / 11)$ & $15(5 / 9)$ \\
\hline 8. Who controls the family financial matters? & $16(10 / 6)$ & $24(10 / 14)$ \\
\hline
\end{tabular}

The presence of a child may influence a parent's enthusiasm in his/her career life as well. Question 6,7 and 8 indicate that men are more likely to be the economic leader of a family when the child is male. However, when the child is female mothers tend to be the leader. It is 
not clear which factor is causing the other. Additionally, the survey respondents may come from multi-children families.

One argument for why having a child which is the same gender as oneself may affect one's motivation to earn is found in 'common identity'. A mother may agree with her female child buying new jewellery, whereas the same may be the case when a father agrees with his male child buying a new car. The opposite-gendered parent may not emphatise as strongly with regards to consumption preferences. This increased consumption motivates the need for higher income of parents with the same gender as their child.

Many cultures are rooted in historical beliefs that men should make more money, contribute more and have an overall upper hand in the family, making women financially dependent on their husbands. Therefore in communities where this is true, a father's choice to be involved in the marriage has a huge overall effect on the success of the marriage.

In certain communities, the gender of a child plays a pivotal role in the level of education they receive and the narrowed down choice of occupation that he/she is likely to choose. Moreover, our data suggests that the gender of a child affects the behaviour of parents. Lundberg and Rose (2002) - data collected from USA - find that there was a hike in the wages and labour supply of men in response to the birth of male children. No differences in wages were noticed in that of women. Another research suggests a woman is more likely to marry the child's father after a nonmarital birth if the child is a son (Lundberg and Rose 2001).

\section{THE COST OF DIVORCE}

Despite so far discussing the benefits of having a male child and its link with the divorce rate, men may play a stronger role in determining the likelihood of divorce based on the economic /monetary consequences of divorce. Most men who opt for divorce are immediately financially better off as they preserve a significant labour earnings as they typically do not pay large amounts of alimony and/or child support to their ex-wives and on the other hand, women and children(s) implicated in separation are often much financially worse off. However growth in an ex-wife's income may be contributed from the new husband's labour 
income if she remarries (Greg J. Duncan, 1985). In families where women are reliant on the men for financial support, men have a stronger role in determining the stability of marriage, therefore in turn explaining why a male child has a tendency to reduce divorce rates relative to a female child.

\section{CONCLUSION}

From our research we conclude that the demand for a male child is higher than for a female child. In addition, men are more persistent in acquiring a second child if the first child is female and female children are not their first preference.

Along the lines of the 'father involvement hypothesis' by Morgan et al (1988) we find that a child will tend to identify the same-gender parent as the leader of the family. This argument can also be used to understand why fathers tend to earn and invest more in a male child.

Overall, while one could argue that a daughter may increase a mother's involvement in a marriage, a father's involvement may be more influential on divorce probabilities due to men tending to have a higher income.

While most of the research work undertaken has been done in developed countries, a clear direction forward is the sensitivity of the results to cultural differences. 


\section{References}

Becker, G.S., Landes, E.M. \& Michael, R.T. (1977). ‘An Economic Analysis of Marital Stability'. Journal of Political Economy, 85: 1141-97.

Diekmann, A. and Schmidheiny, K. (2004). 'Do parents of girls have a higher risk of divorce? An Eighteen-Country Study'. Journal of Marriage and the Family 66: 651-60.

Duncan, G. J., Hoffman, S. D. (1985). 'Economic consequences of marital instability'. In Horizontal Equity, Uncertainty, and Economic Well-Being, ed. M. David, T. Smeeding, pp. 427-67. Chicago: Univ. Chicago Press.

Durkheim, E. (1933). The Division of Labor in Society. New York: Macmillan.

Mammen, K. (2007). 'The Effect of Children's Gender on Divorce and Child Support'. Mimeo, Department of Economics, Barnard College.

Morgan, P. S., D. N. Lye, and G. A. Condran. (1988). 'Sons, Daughters, and the Risk of Marital Disruptions'. American Journal of Sociology 94: 110-29.

White, L. K. (1991). 'Determinants of divorce: A review of research in the eighties'. In A. Booth (Ed.), Contemporary families: Looking forward, looking back pp. 141-149. Minneapolis: National Council on Family Relations. 